\title{
TENDINOPATHY OF THE LONG HEAD OF THE BICEPS TENDON - PHYSICAL EXAMINATION CONFRONTED WITH SHOULDER ARTHROSCOPY FINDINGS
}

\author{
TENDINOPATIA ŚCIĘGNA GŁOWY DŁUGIEJ MIĘŚSIA DWUGŁOWEGO RAMIENIA \\ - KONFRONTACJA BADANIA PRZEDMIOTOWEGO \\ Z WYNIKAMI ARTROSKOPII BARKU
}

Departament of Orthopedics and Traumatology, Multidisciplinary Hospital Inowroclaw, Poland

S u m m a r y

Tendinoapthy is a common medical problem and its aetiopathology is multifactorial. Biceps tendon is more vulnerable to injurie due to anatomic and biomechanical conditions. The aim of the study was to present results of the physical examination and shoulder arthroscopy findings among patients suffering from biceps tendon tendinopathy.

The research was divided into two phases: preoperative and arthroscopic. First phase consisted of clinical examination- five clinical tests, level of pain assessment by use of VAS scale and analysis of the history of disease. Second phase presented 25 patients who underwent shoulder arthroscopy assisted biceps tendon tenotomy or tenodesis.
Clinical examination showed that the most accurate test for biceps tendon tendinopathy was tenderness in the bicipital groove. Mean VAS score was: 7.8. History of subjects tendinopathy was half traumatic and half overuse aetiology. Shoulder arthroscopy revealed other injuries and the most frequent accompanying lesions were rotator cuff tears.

The association between biceps tendon tendinopathy and other shoulder pathologies and problems with accuracy of clinical test have been noted by many authors. Due to so many accompanying lesions, diagnosis of biceps tendon tendinopathy needs to be supported by other diagnostic methods and shoulder arthroscopy is widely accepted as a gold standard to identify biceps tendon pathology.

\section{Streszczenie}

Tendinopatia jest powszechnym problemem medycznym o wieloczynnikowej etiologii. Ścięgno głowy długiej mięśnia dwugłowego ramienia jest podatne na urazy $\mathrm{z}$ powodu uwarunkowań anatomicznych oraz biomechanicznych.

Celem badania było przedstawienie wyników badania przedmiotowego oraz wyników artroskopii barku u pacjentów $\mathrm{z}$ tendinopatią ścięgna bicepsa.

Badanie podzielono na dwie fazy:przedoperacyjną oraz artroskopową. Pierwsza faza składała się z pięciu testów klinicznych,oceny poziomu bólu za pomocą skali VAS oraz analizy historii schorzenia.Druga faza polegała na artroskopii barku z wykonaniem tenotomii lub tenodezy ścięgna bicepsa.

Badanie przedmiotowe wykazało, że najbardziej precyzyjnym testem do oceny tendinopatii ścięgna bicepsa była tkliwość w bruździe międzyguzkowej. Średni wynik w oparciu o skalę VAS to 7,8 . Wywiad schorzenia był w połowie urazowy, a w połowie o przeciążeniowej etiologii. Artroskopia barku ujawniła inne schorzenia w stawach ramiennych, a najczęstszą zmianą były uszkodzenia stożka rotatorów.

Wielu autorów podkreśla związek pomiędzy tendinopatią bicepsa a innymi uszkodzeniami barku oraz problematykę precyzji testów klinicznych w diagnostyce tendinopatii. W obliczu licznych zmian towarzyszących tendinopatii bicepsa diagnostyka powinna być poszerzona o inne badania obrazo-we oraz artroskopię barku uznawaną jako złoty standard.

Key words: biceps tendinopathy, shoulder arthroscopy, Speed test, Yergason test, biceps tendon Slowa kluczowe: tendinopatia bicepsa, artroskopia barku, test Speed, test Yergason, ścięgno bicepsa 


\section{INTRODUCTION}

Tendinopathy is a medical term describing chronic tendon disease. The aetiopathology is multifactorial [1]. In literature we can find three main theories about genesis of tendinopathy: mechanical, vascular and neural theory. Certain tendons are more vulnerable to injurie and damage [2]. Repetitive trauma surpass tendon's poor ability to regeneration.

Biceps tendon pathology is a common cause of anterior shoulder pain. Biceps tendon is exposed to microtrauma during movement of the shoulder- it is called 'overuse symptom' [1, 3, 4, 5]. Additional risk factor of trauma to tendon is accompaniment of other shoulder pathologies.[1] There is a close correlation between biceps tendinopathy and other shoulder lesions - up to 90\%.[6] Rotator cuff tears (RCT) and impingement of subacromial space are exposed and prone biceps tendon to injury. [7]

Current views on the long head of biceps tendon (LHBT) biomechanics revealed evolutionary movement of the scapula and humerus. The scapula is moved to more frontal position and humerus proximal end is positioned into minor retroversion. Bicipital groove in a result of these changes is lying at an angle of $30^{\circ}$. LHBT during movement on the lesser tuberosity is a subject of a new type of force and prone to injurie [8].

The anatomy of LHBT is unique. LHBT is divided into two parts: extra-articular and intra-articular. The LHBT arises from the glenoid labrum and the supraglenoid tubercle. The intra-articular part passes over the head of the humerus before entering the bicipital groove, then it becomes the extra-articular part. [8] LHBT exits the glenohumeral joint between subscapularis tendon and supraspinatus tendon in a space called rotator interval. It enters the bicipital groove where it is covered by the transverse ligament. Superior glenohumeral ligament and coracohumeral ligament, deep fibers of subscapularis and supraspinatus tendons stabilize biceps tendon - form a pulley. Pulley protects antero-medial migration and luxation. Vascularity of biceps tendon arises from branches of brachial artery [3].

Biceps tendon plays a role in a humeral head depression, and is a weak abductor of the shoulder, contributing only $7 \%$ to $10 \%$ of power. Some authors point to the role of the LHBT as a secondary glenohumeral stabilizer $[4,6,8]$.
Symptoms of biceps tendinopathy are: pain radiating down to arm and elbow, pain localized in the anterior part of shoulder, pain in the night and in the rest time, clack of subluxation or luxation during rotation movement [8].

The most common clinical tests for diagnosis of biceps tendinopathy are $[3,7,8]$ :

- Tenderness over bicipital groove: palpation of the biceps tendon located in the bicipital groove in $10^{\circ}$ of internal rotation provoke pain, $3-6 \mathrm{~cm}$ below the anterior margin of the acromion.

- Speed test: Crenshaw and Kilgore first described test in 1966. Patient sits with elbow extended and forearm in supination, the arm is elevated to $90^{\circ}$. Patient is asked to resist force directed downward. The test is positive when the pain is localized in the bicipital groove area.

- Yergason test: The patient is seated with elbow flexed to $90^{\circ}$. Patient is asked to externally rotate the shoulder and supinate the forearm against resistance. Positive test - local pain or tenderness in the bicipital groove .If the tendon pops out of the bicipital groove, we should suspect a lax or ruptured transverse humeral ligament.

- O'Brien test (Active Compression test): in 1998 $\mathrm{O}$ 'Brien and colleagues reported the use of test to differentiate between ACJ (acromio-clavicular joint) pathology and SLAP (superior labrum anterior to posterior) pathology. The patient in sitting or standing position, the upper extremity to be tested is placed in a position of $90^{\circ}$ of shoulder flexion and $10^{\circ}$ of horizontal adduction. The patient then completely internally rotates at the shoulder and pronates at the elbow. The practitioner provides distal stabilizing force as the patient is instructed to apply upward force. The procedure is then repeated in a shoulder and forearm neutral position. A positive test occurs with pain reproduction or clicking in the shoulder with the first position and reduced/absent with the second position. Depth of symptoms must also be assessed as superficial pain can indicate ACJ symptoms and deep pain is more often a sign of labral symptoms. This test is often also positive in patients with LHBT tendinopathy.

- Hawkins-Kennedy test (Impingement test): was first described in 1980.The patient is in a sitting position. The examiner moves the arm of the shoulder to be tested such that the arm is in $90^{\circ}$ of forward 
flexion and the elbow is flexed to $90^{\circ}$.In the starting position the examiner forcefully moves the patient's shoulder into internal rotation to the end or range of motion or until reports of pain. The Hawkins-Kennedy test is considered positive if pain is reported in the superior - lateral aspect of the shoulder. Structures involved in this test are: supraspinatus tendon (SST), subacromial bursa, LHBT.

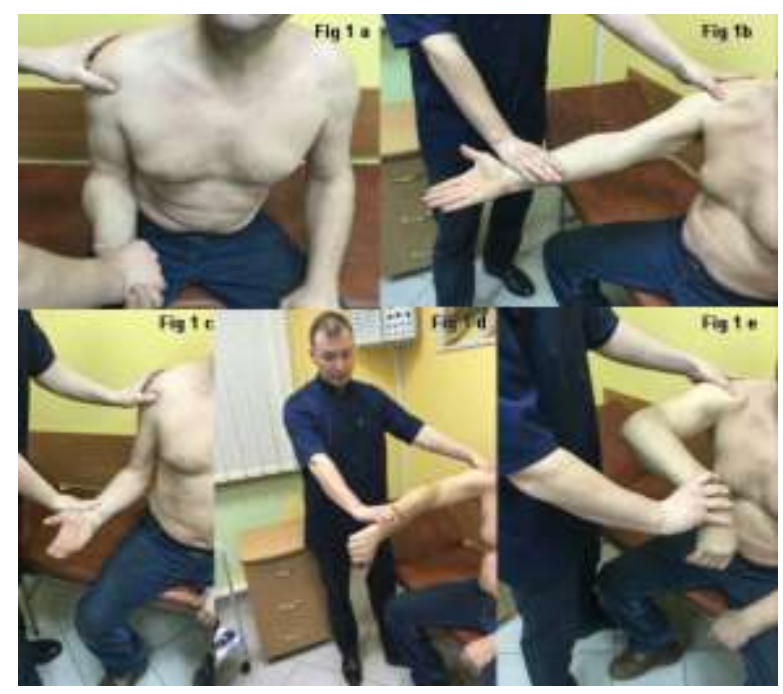

Fig. 1. Clinical tests: 1a-tenderness over bicipital groove test, $1 b$-Speed test, $1 c-$ Yergason test, $1 d-O$ 'Brien test, Fig. 1e-Hawkins-Kennedy test

Ryc. 1. Testy kliniczne: 1a-tkliwość nad bruzda międzyguzkowa, $1 b$ - test Speed, 1c - test Yergason, 1d-test O'Brien, le - test Hawkins-Kennedy

The widespread use of shoulder arthroscopy brought into light the important role of the LHB in many conditions of the shoulder [8]. Arthroscopic tenodesis and tenotomy are popular and commonly accepted methods of treatment of biceps tendinopathy.

Tenotomy is a simple and reproducible technique. It was first described in French literature in 1990. This method of treatment allows cutting off the intraarticular, proximal part of LHBT tendon near the supraglenoid tubercule. Distal part of the tendon retracts into bicipital groove. It provides pain relief, fast return to activity and does not demand postoperative rehabilitation. Disadvantages of this method are cosmetic deformity - 'popeye sign',, loss of supination strength and fatigue $[3,8]$.

Tenodesis allows maintaining the length-tension relation of LHBT, preserves the arm contour and muscle atrophy. LHBT after tenodesis ensures normal forearm supination and elbow flexion. Disadvantages of this method are longer rehabilitation, more demanding procedures - fixation of the tendon to the area of bicipital groove $[3,8]$.

The purpose of this study was to perform results of the physical examination and shoulder arthroscopy findings among patients suffering from LHBT tendinopathy.

\section{METHODS}

Research includes 28 patients who underwent shoulder arthroscopy due to biceps tendinopathy and other supplementary complaints: subacromial impingement, rotator cuff tears, and cartilage and labral defects. Mean age was 53 years old. Of the patients 15 were women and 13 were men.

Research was divided into 2 phases- preoperative and shoulder arthroscopy.

I phase consists of: clinical examination, VAS scale assessment and analysis of the history of disease. We performed the following clinical tests: Tenderness over bicipital groove, Speed test, Yergason test, O'Brien test, Hawkins - Kennedy test.

VAS scale is a measurement instrument that measures the amount of pain that a patient feels in the range from none to an extreme amount of pain. Every patient assesses the pain choosing the number on the visual scale from 0 to 10 , where 0 indicates no pain and 10 indicates most severe pain. Medical interview with patient provided history of duration of disease: $<1$ year ,1-2 years, >2 years; and let us to classify the aetiolgy of tendinopathy in traumatic and overuse.

II phase consists of arthroscopic evaluation of the shoulder used as a gold standard.

Shoulder arthroscopy was performed in beach chair position. Joint distension was provided by pump with pressures of $50-80 \mathrm{mmHg}$. The rotator cuff, intraarticular part of biceps tendon, labrum, ligaments, glenoid and humeral head cartilage were inspected. All patients had arthroscopy assisted tenotomy or tenodesis of the LHBT. Shoulder arthroscopy let us to visualize structure and vessel pattern of the tendon, examine the luxation or subluxation from bicipital groove by use of the arthroscopic probe.

\section{RESULTS}

Results of I phase - clinical examination was characterized by: $89 \%$ of patients demonstrated tenderness over bicipital groove as positive $.71 \%$ of patients demonstrated Speed test and Yergason test as 
positive. $46 \%$ of patients demonstrated Hawkins and O'Brien tests as positive and $35 \%$ as doubt.

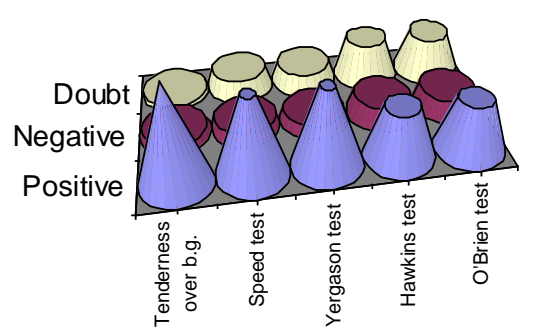

Chart 1. Outcomes of preoperative clinical tests

Wykres 1. Wyniki przedoperacyjnego badania przedmiotowego

The range of scores in VAS scale was 5-9. The mean VAS scale score was 7.5.

Analysis of the history of disease shows that there were 2 main groups: 7 people with traumatic aetiology and duration of symptoms for less than 1 year and 10 people with overuse aetiology and duration of symptoms for over 2 years. Patients belonging to the second group were mainly physical workers and craftsmen.

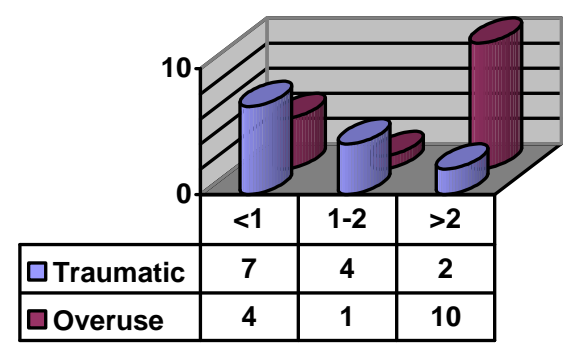

Chart 2. Analysis of the tendinopathy's aetiology

Wykres 2. Analiza etiologii tendinopatii

In both groups night pains were common and did not pass after non-steroidal anti-inflammatory drugs.

Results of II phase - Arthroscopic evaluation of the shoulder of 28 patients performed that biceps tendinopathy was accompanied in $96 \%$ by another intra-articular lesion. Five patients underwent tenotomy procedure and 22 patients underwent tenodesis procedure. One patient had biceps stub after complete rupture of tendon, which was removed. Six patients had biceps tendon dislocation. One had complete tendon rupture and migration to bicipital groove and stuck under the pulley.

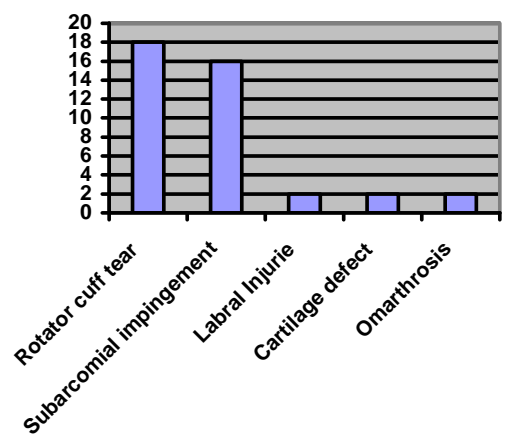

Chart 3. Additional lesions among patients underwent shoulder arthroscopy due to LHBT tendinopathy

Wykres 3. Dodatkowe zmiany wśród pacjentów poddanych artrosopii barku z powodu tendinopatii bicepsa
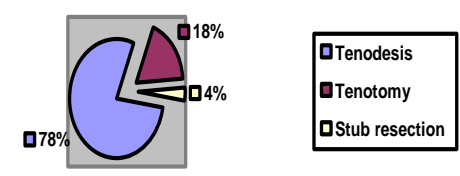

Chart 4. Distribution of arthroscopic procedures

Wykres 4. Rozkład procentowy procedur artroskopowych

\section{DISCUSSION}

Patients that suffer from rotator cuff tears, impingement syndrome often have LHBT tendinopathy and anterior shoulder pain. It is difficult to diagnose in patients with plenty of intra-articular lesions. Some subjects $4-35 \%$ in different clinical tests had limited range of movement and were unable to completely fulfill clinical tests, due to painful conditions. This is the reason why the tests were doubtful. Some of the patients suffer from such severe pain that were unable to localize the origin of the pain as it expanded over the whole shoulder. Isolated tendinopathy as a single lesion in the shoulder is very rare phenomenon.

In this paper the most accurate test for LHBT tendinipathy was tenderness over b.g. - positive among $89 \%$ of patients. Speed and Yergason tests had less accuracy $-71 \%$. Hawkins and O'Brien test's accuracy was about $46 \%$. Hawkins and O'Brien tests are also involved in SST tear, impingement and ACJ lesions.

None of these tests can accurately predict LHBT tendinopathy. Tenderness over bicipital groove had the best accuracy and this is the most popular test in literature and also in common clinical examination. 
Pain in the bicipital groove, likewise to others clinical tests, may be also confused by other shoulder lesions.

The association between LHBT tendinopathy and other shoulder injuries and problem with accuracy of clinical test were noted by many authors [4]. Vamsi et al. identified LHBT tendinopathy as a significant source of anterior shoulder pain . They noted only $49 \%$ of visible damaged of the LHBT during arthroscopy but tenodesis assisted arthroscopy provided pain relief. Clinical tests were not completely consistent with arthroscopic findings. They recommend use of imaging techniques for example ultrasound and magnetic resonance imaging to aid clinical evaluation. Authors proclaim that LHBT is not a sole source of anterior shoulder pain. Patients they had referred to tenodesis procedure had variable concurrent pathologies beyond LHBT tendinopathy [7]. Harpreet S. et al. described that of 40 patients who underwent shoulder arthroscopy $85 \%$ of biceps tears were accompanied by RCT and $7.5 \%$ were accompanied by anterior instability. They prove that no single clinical test can accurately predict the presence of the biceps tear. They recommend diagnostic arthroscopy [9]. Jonathan J Streit et al. examined 26 patients who underwent shoulder arthroscopy. Clinical examination includes: Speed test, O'Brien test, tenderness within bicipital groove during palpation. Preoperative clinical examination showed that: $93 \%$ of patients demonstrated positive Speed and O'Brien test and tenderness over bicipital groove was positive in every case. Additional arthroscopy findings among patients were: subacromial impingement, rotator cuff tear, SLAP. They claim that anterior shoulder pain is often found in presence of subacromial impingement and other intra-arcticular lesions [10]. Holtby R. et al. evaluated accuracy of the Speed's and Yergason's tests in detecting biceps pathology and SLAP lesions. Authors compare clinical tests with arthroscopic findings. Fifty subjects underwent shoulder arthroscopy. Tests were moderate, specific and did not provide complete preoperative diagnosis.

This paper shows correlation between VAS scale and clinical examination of the shoulder. All patients demonstrated advanced tendinopathy accompanied by other lesions and mean VAS score was 7.5. VAS score evince usefulness and convenience in examining subject's pain experience. A great part of subjects report night pain, with no relief after non-steroidal antiinflammatory drugs [4]. Vamsi et al. also used VAS scale and mean score was similar -7.8 .

\section{TENOTOMY OR TENODESIS?}

We performed 5 tenotomies and 22 tenodesis. Tenodesis procedure dominates among patients with mean age of 53 years old. Authors suggest biceps tenotomy in patients over 55-60 years old. On the other hand, heavy laborers and younger active patients may benefit from tenodesis. Patients who underwent tenodesis procedure must be informed about strict rehabilitation program and restriction of shoulder movement for 6 weeks $[3,8]$.

\section{SUMMARY}

Patient with LHBT tendinopathy had mostly another shoulder pathologies.

Clinical tests are not sensitive and specific enough, mainly because of other intra-articular damage concealing. Diagnosis by physical examination is not enough reliable way to identify biceps tendinopathy. In the face of so many accompanied lesions accuracy of clinical tests is controversial. Diagnosis of LHBT tendinopathy should be performed with auxiliary methods of imaging .Shoulder arthroscopy is a gold standard to identify LHBT pathology.

\section{REFERENCES}

1. Joseph M, Maresh CM, McCarthy MB,et al. Histological and molecular analysis of biceps tendon, 2009,J Orthop Res. Oct;27(10):1379-85.

2. Rees JD, Wilson AM, Wolman RL, Current concepts in the management of tendon disorders, 2006, Rheumatology (Oxford); 45(5):508-21.

3. Ditsios K, Agathangelidis F, Boutsiadis A ,et al. Long Head of the Biceps Pathology Combined with Rotator Cuff Tears, 2012, Adv Orthop. :405-472.

4. Singaraju VM, Kang RW, Yanke $A B$, et al. Biceps tendinitis in chronic rotator cuff tears: a histologic perspective. 2008, J Shoulder Elbow Surg.;17(6):898904.

5. Riley G. The pathogenesis of tendinopathy. A molecular perspective 2004Rheumatology (Oxford).;43(2):131-42.

6. Sethi N, Wright R, Yamaguchi K. Disorders of the long head of biceps tendon ,1999, J Shoulder Elbow Surg.; 8(6):644-54.

7. Gill HS, El Rassi G, Bahk MS,et al. Physical examination for partial tears of biceps tendon. 2007 Am J Sports Med. ;35(8):1334-40.

8. P. M. Ahrens, P. Boileau, The long head of biceps and associated tendinopathy, 2007 ,J Bone Joint Surg Br.;89(8):1001-9.

9. Streit JJ, Shishani Y, Rodgers M, et al. Tendinopathy of the long head of the biceps tendon: histopathologic 
analysis of the extra-articular biceps tendon and tenosynovium. 2015 ,Open Access J Sports Med.;6:6370 Holtby R, Razmjou H. Accuracy of the Speed's and Yergason's tests in detecting biceps pathology and SLAP lesions: comparison with arthroscopic findings. 2004,Arthroscopy:;20(3):231-6.

\section{Address for correspondence:}

Szpital Wielospecjalistyczny w Inowrocławiu Oddział Ortopedyczno-Urazowy

88-100 Inowrocław ul. Poznańska 97

Lek.med. Jan Zabrzyński

telefon/fax: (52) 3545478

e-mail:zabrzynski@gmail.com

Received: 30.03.2016

Accepted for publication: 10.06.2016 